\section{A Fluorescence Sensor for Detection of Geranyl Pyrophosphate by the Chemo-Ensemble Method}

\author{
Kuan-Hung Chen, Jen-Hai Liao, Hsin-Yu Chan, and \\ Jim-Min Fang* \\ Department of Chemistry, National Taiwan University,
Taipei, 106, Taiwan \\ jmfang@ntu.edu.tw
}

Received October 09, 2008

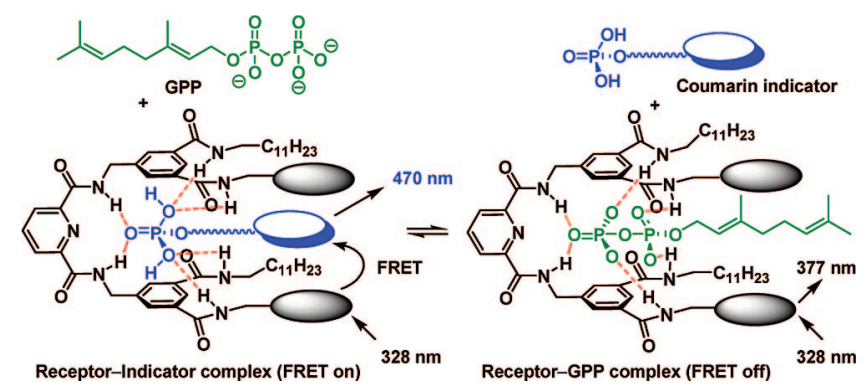

Hexaamide receptor $\mathbf{4}$ and coumarin phosphate $\mathbf{5}$ form an ensemble for effective sensing of geranyl pyrophosphate (GPP). Fluorescence resonance energy transfer in the $\mathbf{4}+\mathbf{5}$ ensemble diminishes when $\mathbf{5}$ is replaced by GPP. Receptor 4 binds selectively with GPP over other anions, including fatty acids. The 4-GPP complex in 1:1 stoichiometry is inferred by NMR and fluorescence titrations. Receptor 4 contains a pseudotetrahedral cleft to accommodate GPP via multiple hydrogen bonds, and the two aliphatic chains exert additional hydrophobic interactions.

The selective recognition and sensing of phosphate and pyrophosphate ions has been the main focus of research, ${ }^{1-3}$ because these ions play essential biological roles in metabolism of fatty acids, sugars, and isoprenoids. ${ }^{4}$ The inherent tetrahedral structure of phosphate ion disposes a challenging problem for

(1) (a) Beer, P. D.; Gale, P. A. Angew. Chem., Int. Ed. 2001, 40, 486-516. (b) Martínez-Máñez, R.; Sancanón, F. Chem. Rev. 2003, 103, 4419-4476.

(2) (a) Liao, J.-H.; Chen, C.-T.; Fang, J.-M. Org. Lett. 2002, 4, 561-564. (b) Liao, J.-H.; Chen, C.-T.; Fang, J.-M. J. Chin. Chem. Soc. 2006, 53, 1439 1446. (c) Yoon, J.; Kim, S. K.; Singh, N. J.; Lee, J. W.; Yang, Y. J.; Chellappan, K.; Kim, K. S. J. Org. Chem. 2004, 69, 581-583. (d) Singh, N. J.; Jun, E. J.; Chellappan, K.; Thangadurai, D.; Chandran, R. P.; Hwang, I.-C.; Yoon, J.; Kim, K. S. Org. Lett. 2007, 9, 485-488.

(3) (a) Lee, D. H.; Kim, S. Y.; Hong, J.-I. Angew. Chem., Int. Ed. 2004, 43, 4777-4780. (b) Cho, H. K.; Lee, D. H.; Hong, J.-I. Chem. Commun. 2005, 16901692. (c) McDonough, M. J.; Reynolds, A. J.; Lee, W. Y. G.; Jolliffe, K. A. Chem. Commun. 2006, 2971-2973. (d) Lee, H. L.; Park, J.; Lah, M. S.; Chin, J.; Hong, J.-I. Org. Lett. 2007, 9, 3729-3731. (e) Morgan, B. P.; He, S.; Smith, R. C. Inorg. Chem. 2007, 46, 9262-9266. (f) Shao, N.; Jin, J. Y.; Wang, G. L.; Zhang, Y.; Yang, R. H.; Yuan, J. L. Chem. Commun. 2008, 1127-1129.

(4) (a) Schmidtchen, F. P.; Berger, M. Chem. Rev. 1997, 97, 1609-1646. (b) Beer, P. D. Acc. Chem. Res. 1998, 31, 71-80. (c) Nelson, D. L.; Cox, M. M. Lehninger Principles of Biochemistry; Worth Publishers: New York, 2000; pp 602,735 , and 801 . the design of effective receptors. For selective binding with phosphate and pyrophosphate ions, many synthetic receptors contain polyaza, quanidinium, imidazolium, urea, thiourea, and amide groups in appropriate dispositions to exert the desired electrostatic interactions and hydrogen bondings. ${ }^{1,2}$ Alternatively, the metal-ligand interaction is widely applied to recognize the phosphate groups. ${ }^{1,3}$

The methods for effective sensing of biologically important organic phosphate molecules are in embryonic development, and most studies focus on the design of optical chemosensors for detection of nucleotides, ${ }^{5-7}$ such as adenosine triphosphate (ATP). A nucleotide chemosensor often incorporates a moiety to bind with the nitrogenous base in the specific nucleotide, in addition to the moiety for binding with mono-, di-, or triphosphates. Crick-Watson pairs ${ }^{6}$ and (hetero)aromatic hydrocarbons ${ }^{7}$ are often designed to provide multiple hydrogen bonding, hydrophobic, and $\pi-\pi$ interactions with nitrogenous bases. Furthermore, dinuclear zinc-dipicolylamine complexes have been employed as the effective sensors of adenosine monophosphate (AMP) and uridine diphosphate (UDP) in enzyme activity assays. ${ }^{8}$ Several research groups have also explored the optical chemosensors for inositol-1,4,5-trisphosphate, ${ }^{9}$ lysophosphatidic acid (LPA), ${ }^{10}$ 2,3-bisphosphoglycerate, ${ }^{11}$ and phosphatidylserine on membranes. ${ }^{12}$ However, the optical method for sensing isoprenyl pyrophosphates has not yet been reported.

Isoprenyl pyrophosphates are known to involve in the regulation of cell growth and division. ${ }^{13}$ Consecutive condensa-

(5) (a) Eliseev, A. V.; Schneider, H.-J. J. Am. Chem. Soc. 1994, 116, 60816088. (b) Shih, H.-C.; Tang, N.; Burrows, C. J.; Rokita, S. E. J. Am. Chem. Soc. 1998, 120, 3284-3288. (c) Ojida, A.; Park, S.-K.; Mito-oka, Y.; Hamachi, I. Tetrahedron Lett. 2002, 43, 6193-6195. (d) Chen, H.; Parkinson, J. A.; Morris, R. E.; Sadler, P. J. J. Am. Chem. Soc. 2003, 125, 173-186. (e) McCleskey, S. C.; Griffin, M. J.; Schneider, S. E.; McDevitt, J. T.; Anslyn, E. V. J. Am. Chem. Soc. 2003, 125, 1114-1115. (f) Kim, S. K.; Moon, B.-S.; Park, J. H.; Seo, Y. I.; Koh, H. S.; Yoon, Y. J.; Lee, K. D.; Yoon, J. Tetrahedron Lett. 2005, 46, 66176620. (g) Li, C.; Numata, M.; Takeuchi, M.; Shinkai, S. Angew. Chem., Int. Ed. 2005, 44, 6371-6374. (h) Wang, S.; Chang, Y.-T. J. Am. Chem. Soc. 2006, 128, $10380-10381$.

(6) (a) Furuta, H.; Magda, D.; Sessler, J. L. J. Am. Chem. Soc. 1991, 113, 978-985. (b) Král, V.; Sessler, J. L.; Furuta, H. J. Am. Chem. Soc. 1992, 114, 8704-8705. (c) Kato, Y.; Conn, M. M.; Rebek, J., Jr J. Am. Chem. Soc. 1994, 116, 3279-3284. (d) Bell, T. W.; Zheng, H.; Zimmerman, S. C.; Thiessen, P. A. Angew. Chem., Int. Ed. 1995, 34, 2163-2165. (e) Nakatani, K.; Sando, S.; Kumasawa, H.; Kikuchi, J.; Saito, I. J. Am. Chem. Soc. 2001, 123, 12650-12657.

(7) (a) Hosseini, M. W.; Blacker, A. J.; Lehn, J.-M. J. Chem. Soc., Chem. Commun. 1988, 9, 596-598. (b) Abe, H.; Mawatari, Y.; Teraoka, H.; Fujimoto, K.; Inouye, M. J. Org. Chem. 2004, 69, 495-504. (c) Kejík, Z.; Záruba, K.; Michalík, D.; Aebek, J.; Dian, J.; Pataridis, S.; Volka, K.; Král, V. Chem. Commun. 2006, 1533-1535. (d) Neelakandan, P. P.; Hariharan, M.; Ramaiah, D. J. Am. Chem. Soc. 2006, 128, 11334-11335.

(8) (a) Han, M. S.; Kim, D. H. Bioorg. Med. Chem. Lett. 2003, 13, 10791082. (b) Wongkongkatep, J.; Miyahara, Y.; Ojida, A.; Hamachi, I. Angew. Chem., Int. Ed. 2006, 45, 665-668.

(9) Niikura, K.; Metzger, A.; Anslyn, E. V. J. Am. Chem. Soc. 1998, 120, $8533-8534$

(10) (a) Alpturk, O.; Rusin, O.; Fakayode, S. O.; Wang, W. H.; Escobedo, J. O.; Warner, I. M.; Crowe, W. E.; Kral, V.; Pruet, J. M.; Strongin, R. M. Proc. Natl. Acad. Sci. U.S.A. 2006, 103, 9756-9760. (b) Chen, K.-H.; Yang, J.-S.; Hwang, C.-Y.; Fang, J.-M. Org. Lett. 2008, 10, 4401-4404.

(11) Zhong, Z.; Anslyn, E. V. Angew. Chem., Int. Ed. 2003, 42, 3005-3008.

(12) (a) Lakshmi, C.; Hanshaw, R. G.; Smith, B. D. Tetrahedron 2004, 60, 11307-11315. (b) Hanshaw, R. G.; O’Neil, E. J.; Foley, M.; Carpenter, R. T.; Smith, B. D. J. Mater. Chem. 2005, 15, 2707-2713.

(13) (a) Sinensky, M.; Logel, J. Proc. Natl. Acad. Sci. U.S.A. 1985, 82, 32573261. (b) Rilling, H. C.; Breunger, E.; Epstein, W. W.; Crain, P. F. Science 1990, 247, 318-320. (c) Farnsworth, C. C.; Gelb, M. H.; Glomset, J. A. Science 1990, 247, 320-322. (d) Cane, D. E. Chem. Rev. 1990, 90, 1089-1103. 
tion of isoprenyl pyrophosphates produces geranyl pyrophosphate (GPP), farnesyl pyrophosphate, and many other important derivatives. The common methods for determination of isoprenyl pyrophosphates include HPLC, GC-MS, and capillary electrophoresis, which often require prior treatments with enzyme, acid, or radioisotope. ${ }^{14-18}$ It is demanding to explore an effective method for the sensing of isoprenyl pyrophosphates. To demonstrate this idea, we utilize a hexaamide receptor $4\left(\mathrm{R}^{1}=\right.$ $\mathrm{C}_{11} \mathrm{H}_{23}, \mathrm{R}^{2}=$ pyrenyl) and an indicator of coumarin phosphate 5 to build up an ensemble system for the sensing of isoprenyl pyrophosphate GPP (6). The binding behavior of hexaamide molecules $\mathbf{1}\left(\mathrm{R}^{1}=\mathrm{R}^{2}=\mathrm{H}\right), \mathbf{2}\left(\mathrm{R}^{1}=\mathrm{R}^{2}=\right.$ pyrenyl $)$, and $\mathbf{3}\left(\mathrm{R}^{1}\right.$ $\left.=\mathrm{R}^{2}=\mathrm{C}_{11} \mathrm{H}_{23}\right)$ was also examined for comparison.

We have previously reported that molecule 2 having the scaffold of pyridine 2,6-bis-carboxamide with four pyreneannexed amido groups provides a preorganized cleft to hold the incoming phosphate and pyrophosphate ions via multiple hydrogen bondings. ${ }^{2 a, b}$ The detailed structural analysis of molecule 2 indicates that the pyrene rings stack in two pairs ( $\mathrm{R}^{1} / \mathrm{R}^{1}$ and $\mathrm{R}^{2} / \mathrm{R}^{2}$ ) by $\pi-\pi$ interactions to give a significant excimer emission $\left(\lambda_{\max }=477 \mathrm{~nm}\right)$. When receptor 2 binds with phosphate or pyrophosphate ions, in 1:1 stoichiometry, ratiometric changes of the monomer and excimer emissions occur in response to the segregation of pyrene rings. We conceived that hexaamide $\mathbf{4}$ having a similar structure to $\mathbf{2}$ would also bind effectively with the pyrophosphate group via multiple hydrogen bondings. Furthermore, the pair of aliphatic chains $\left(\mathrm{R}^{1}=\mathrm{C}_{11} \mathrm{H}_{23}\right)$ in 4 would provide additional hydrophobic interactions with isoprenyl pyrophosphates. The binding event would be readily detected by the fluorescence change of the pyrene rings in 4 .

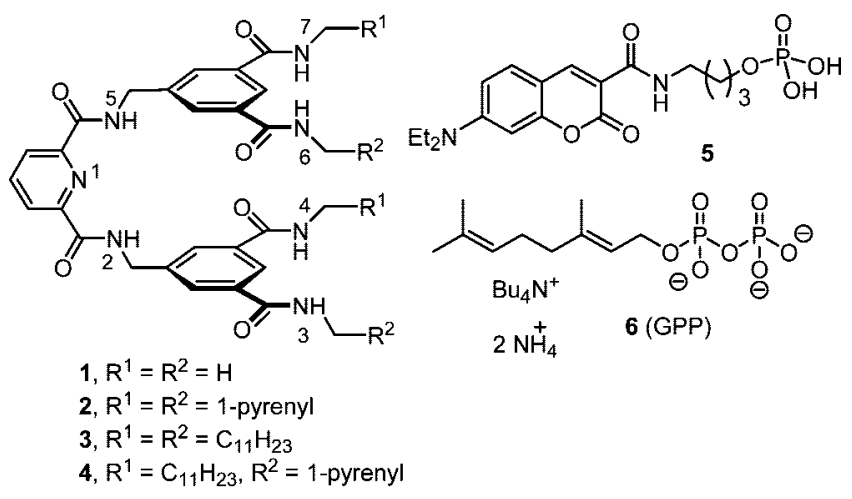

The binding affinity of receptors $1-4$ with $\mathrm{H}_{2} \mathrm{PO}_{4}{ }^{-}$, di(hexadecyl) phosphate (DHP), and GPP was first evaluated by ${ }^{1} \mathrm{H}$ NMR titrations in DMSO- $d_{6}$ solutions. Upon complexation with phosphate substrates, the amido protons in the receptor molecules showed substantial changes of the chemical shifts. For example, addition of GPP (1.375 equiv) to receptor 4 (Figure 1) caused significant downfield shifts of $N_{2}, N_{5}-\mathrm{H}(\Delta \delta=1.1$ ppm), $N_{3}, N_{6}-\mathrm{H}(\Delta \delta=0.6 \mathrm{ppm})$, and $N_{4}, N_{7}-\mathrm{H}(\Delta \delta=0.4 \mathrm{ppm})$. The chemical-shift changes might result from the interactions of the corresponding protons with GPP in different degrees, i.e.,

(14) (a) Bruenger, E.; Rilling, H. C. Anal. Biochem. 1988, 173, 321. (b) McCaskill, D.; Croteau, R. Anal. Biochem. 1993, 215, 142-149.

(15) Fisher, A. J.; Rosenstiel, T. N.; Shirk, M. C.; Fall, R. Anal. Biochem. 2001, 292, 272-279.

(16) Anderson, P. E.; Pfeffer, W. D.; Blomberg, L. G. J. Chromatogr. A 1995, 699, 323-330.

(17) (a) Zhang, D.; Poulter, C. D. Anal. Biochem. 1993, 213, 356-361. (b)

Saisho, Y.; Morimoto, A.; Umeda, T. Anal. Biochem. 1997, 252, 89-95.

(18) Song, L. Anal. Biochem. 2003, 317, 180-185.



FIGURE 1. ${ }^{1} \mathrm{H}$ NMR titration of receptor $\mathbf{4}\left(2.4 \times 10^{-3} \mathrm{M}\right)$ with GPP $\left(0.3 \mathrm{M}\right.$ as the tetrabutylammonium salt) in DMSO- $d_{6}$ solution.

TABLE 1. Association Constants $K_{\mathrm{a}}\left(\mathrm{M}^{-1}\right)$ in DMSO- $d_{6}$ Solutions As Determined by the ${ }^{1} \mathrm{H}$ NMR Titrations ${ }^{a}$

\begin{tabular}{cccl}
\hline receptor & $\mathrm{H}_{2} \mathrm{PO}_{4}^{-}$ & DHP & GPP \\
\hline 1 & $950 \pm 140$ & $150 \pm 20$ & $\mathrm{ND}^{b}$ \\
2 & $1370 \pm 200$ & $780 \pm 120$ & $1280 \pm 500$ \\
3 & $960 \pm 140$ & 840 & $2500 \pm 240$ \\
4 & $880 \pm 100$ & $1830 \pm 150$ & $3300 \pm 270$
\end{tabular}

${ }^{a}$ Individual receptor in DMSO- $d_{6}$ solution $\left(2.4 \times 10^{-3} \mathrm{M}\right)$ was titrated with incremental additions of respective substrate in DMSO- $d_{6}$ solution $(0.3 \mathrm{M}) .{ }^{b}$ Not determined.

pyridinecarboxamides $>$ pyrenyl amides $>$ aliphatic amides. This result was consistent with incorporation of GPP inside the cleft of receptor 4 as a 1:1 complex. According to the nonlinear least-squares method, ${ }^{19}$ the association constants $\left(K_{\mathrm{a}}\right)$ were determined by using the chemical-shift changes of $N_{2}, N_{5}-\mathrm{H}$ in an individual receptor as a function of the concentration of phosphate substrates based on a 1:1 stoichiometry of complexation (Table 1).

In comparison, receptor $\mathbf{2}$ exhibited the strongest binding with phosphate ion, presumably due to the preorganization effect rendered by stacking its pyrene rings in pairs. ${ }^{2 \mathrm{~b}, \mathrm{~d}}$ On the other hand, receptor 4 showed the highest affinity in binding with aliphatic phosphates DHP and GPP. This result might be attributable to the synergistic effect of preorganization by a pair of pyrene rings and the hydrophobic interactions exerted by the long hydrocarbon chains. Even though receptor $\mathbf{3}$ has four aliphatic chains to render strong hydrophobic interactions, it lacks pyrene rings for structural preorganization, and thus shows lower affinity with GPP and DHP than receptor 4. Receptor 1 with methylamido groups at the termini only had weak binding with DHP due to lacking effective hydrophobic interactions.

(19) Connors, K. A. Binding Constants-The Measurement of Molecular Complex Stability; John Wiley: New York, 1987. 
The photophysical properties of $\mathbf{4}$ were investigated. Upon excitation at $328 \mathrm{~nm}$, receptor $\mathbf{4}$ showed the monomer emission at $\lambda_{\max }=377$ and $397 \mathrm{~nm}$, as well as the excimer emission at $\lambda_{\max }=477 \mathrm{~nm}$. As the intensity ratio of monomer-to-excimer emissions remained constant in various concentrations $(1.25 \times$ $10^{-6}$ to $\left.10^{-5} \mathrm{M}\right)$, the excimer emission should occur via intramolecular interactions of pyrenes, but not intermolecularly in this concentration range. Though receptor $\mathbf{4}$ had good binding affinity with GPP as shown by the NMR titration experiments, the binding event did not induce appreciable fluorescence change as we expected. A possible explanation is that receptor $\mathbf{4}$ has only one pair of pyrenes, which may still remain in proximity in the 4-GPP complex presumably by assistance of the interactions of aliphatic chains.

We thus designed a chemosensing ensemble $e^{11,20}$ using fluorescence resonance energy transfer $\left(\right.$ FRET) ${ }^{21}$ for an effective detection of the binding event. There are several criteria for choosing the appropriate indicator in an ensemble system. ${ }^{22}$ After we surveyed several possible fluorogenic indicators, we chose coumarin phosphate $\mathbf{5}$ as a FRET acceptor of the monomer emission of pyrenes to establish the ensemble for displacement assay. By ${ }^{1} \mathrm{H}$ NMR titration, the association constant between receptor $\mathbf{4}$ and phosphate $\mathbf{5}$ was deduced to be $1100 \pm 207 \mathrm{M}^{-1}$ in DMSO- $d_{6}$ solution. Thus, the ensemble of $\mathbf{4}+\mathbf{5}$ was reasonably stable, but coumarin $\mathbf{5}$ would be readily replaced by GPP to form a stronger 4-GPP complex, $K_{\mathrm{a}}=$ $3300 \pm 535 \mathrm{M}^{-1}$ in DMSO- $d_{6}$ solution.

In a typical fluorescence titration experiment, a DMSO solution of phosphate $\mathbf{5}$ was added in incremental portions to receptor $4\left(5 \times 10^{-6} \mathrm{M}\right.$ in DMSO $)$. The fluorescence spectra showed consistent decreases in the monomer emission of pyrenes $\left(\lambda_{\max }=395 \mathrm{~nm}\right)$ along with concurrent increases of the coumarin emission at $\lambda_{\max }=470 \mathrm{~nm}$ (Figure 2), supporting a FRET process upon their complexation. ${ }^{23}$ When GPP was added to the $\mathbf{4}+\mathbf{5}$ ensemble (1:1 complex in DMSO solution), the monomer emission of pyrenes was recovered at the expense of the 470-nm emission, indicating that the indicator $\mathbf{5}$ was displaced by GPP in the binding cavity of receptor 4 . On the basis of the emission change at $395 \mathrm{~nm}$, the association constant of the 4-GPP complex was deduced to be $2.3 \pm 0.8 \times 10^{4}$ $\mathrm{M}^{-1}$ in DMSO by a competitive spectrophotometric method. ${ }^{19}$ The $\mathbf{4}+\mathbf{5}$ ensemble was similarly determined to have a $K_{\mathrm{a}}$ value of $4.1 \pm 0.4 \times 10^{3} \mathrm{M}^{-1}$ in DMSO. In comparison, the 2 +5 ensemble $\left(K_{\mathrm{a}}=3.3 \pm 0.7 \times 10^{4} \mathrm{M}^{-1}\right)$ was less sensitive to GPP due to its lower binding affinity to receptor 2 .

In comparison with GPP, the response of phosphate and pyrophosphate ions to the $\mathbf{4}+\mathbf{5}$ ensemble was relatively low (Figure 3). Other examined anions, including $\mathrm{F}^{-}, \mathrm{Cl}^{-}, \mathrm{Br}^{-}$, $\mathrm{SCN}^{-}, \mathrm{AcO}^{-}, \mathrm{NO}_{3}^{-}, \mathrm{ClO}_{4}^{-}$, and the carboxylate ions of fatty acids $\left(\mathrm{C}_{10} \mathrm{H}_{21} \mathrm{CO}_{2} \mathrm{H}\right.$, and $\left.\mathrm{C}_{11} \mathrm{H}_{23} \mathrm{CO}_{2} \mathrm{H}\right)$, were insensitive to the $\mathbf{4}+\mathbf{5}$ ensemble. Thus, the high binding affinity of 4-GPP was attributable not only to the hydrophobic interactions of the aliphatic chains but also to the multiple hydrogen bondings of the tetrahedral pyrophosphate in the hexaamide cleft.

(20) Wiskur, S. L.; Ait-Haddou, H.; Lavigne, J. J.; Anslyn, E. V. Acc. Chem Res. 2001, 34, 963-972.

(21) (a) Wu, P.; Brand, L. Anal. Biochem 1994, 218, 1-13. (b) Li, I. T. Pham, E.; Truong, K. Biotechnol. Lett. 2006, 28, 1971-1982.

(22) Fabbrizzi, L.; Marcotte, N.; Stomeo, F.; Taglietti, A. Angew. Chem., Int. Ed. 2002, 41, 3811-3814.

(23) In comparison with the $\mathbf{4}+\mathbf{5}$ ensemble, coumarin phosphate $\mathbf{5}$ showed much less increase of fluorescence intensity $\left(\lambda_{\max }=470 \mathrm{~nm}\right)$ by excitation at 328 or $340 \mathrm{~nm}$ (see Figure S13 in the SI). The excess increment of fluorescence intensity in the ensemble system was attributable to the FRET effect.



FIGURE 2. (a) Fluorescence titration of $4\left(5 \times 10^{-6} \mathrm{M}\right.$ in DMSO) with incremental addition of 5 (up to 5 equiv, $1 \times 10^{-3} \mathrm{M}$ solution in DMSO). (b) Fluorescence titration of the ensemble $\mathbf{4}+\mathbf{5}$ (1:1 complex, $5 \times 10^{-6} \mathrm{M}$ in DMSO) with incremental addition of GPP (up to 3 equiv, $1 \times 10^{-3} \mathrm{M}$ solution in DMSO). The excitation wavelength was $328 \mathrm{~nm}$

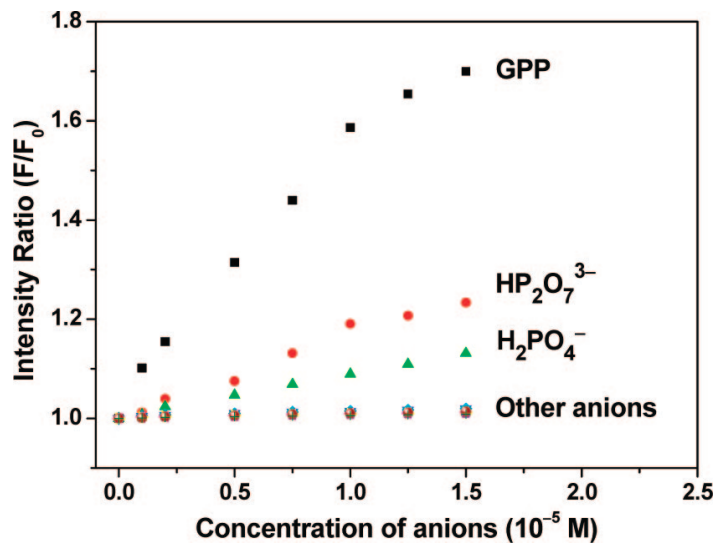

FIGURE 3. Fluorescence calibration curves at $395 \mathrm{~nm}$ for the $\mathbf{4}+\mathbf{5}$ ensemble $\left(1: 1\right.$ complex, $\left.5 \times 10^{-6} \mathrm{M}\right)$ upon addition of various anions in DMSO solution (up to 3 equiv). Other anions: $\mathrm{CH}_{3} \mathrm{CO}_{2}{ }^{-}$, $\mathrm{C}_{10} \mathrm{H}_{21} \mathrm{CO}_{2}{ }^{-}, \mathrm{C}_{11} \mathrm{H}_{23} \mathrm{CO}_{2}{ }^{-}, \mathrm{F}^{-}, \mathrm{Cl}^{-}, \mathrm{Br}^{-}, \mathrm{SCN}^{-}, \mathrm{NO}_{3}{ }^{-}$, and $\mathrm{ClO}_{4}{ }^{-}$.

In summary, we have designed a chemo-ensemble system using FRET as the sensing mechanism to detect isoprenoid pyrophosphates, e.g., GPP in this study. The hexaamide molecule $\mathbf{4}$ has a well-defined structure with pseudotetrahedral cleft to accommodate the pyrophosphate. Receptor $\mathbf{4}$ also incorporates two long hydrocarbon chains to enhance the interactions with the aliphatic moiety of GPP. The coumarin phosphate $\mathbf{5}$ is selected as an appropriate fluorescence indicator because it binds modestly with the receptor 4 to render a FRET from the pyrene rings. Thus, the present chemo-ensemble system provides an efficient, selective, and sensitive method for detection of GPP. This method is potentially useful for selective sensing of other biologically important aliphatic phosphates and pyrophosphates. 


\section{Experiment Section}

$N, N^{\prime}$-Bis $\{[3-($ pyren-1-yl)methylcarbamoyl-5-dodecylcarbamoyl]benzyl \}pyridine-2,6-dicarboxamide (4). By a procedure similar to that described previously, ${ }^{2 \mathrm{a}, \mathrm{b}}$ compound $\mathbf{4}$ was synthesized in a straightforward manner. In brief, 5-(azidomethyl)isophthalic acid was activated to its dipentafluorophenyl ester and subjected to coupling reaction with a mixture of (1-pyrenyl)methylamine and $n$-dodecylamine to give the corresponding diamide. The azido group was reduced to amine, and the subsequent coupling reaction with 2,6-pyridinedicaboxyl dichloride afforded the desired hexaamide receptor 4.

White solid, mp 204-206 ${ }^{\circ} \mathrm{C}$; TLC $\left(\mathrm{CH}_{2} \mathrm{Cl}_{2} / \mathrm{CH}_{3} \mathrm{OH}, 95: 5\right) R_{f}$ $0.8 ;{ }^{1} \mathrm{H}$ NMR (DMSO- $\left.d_{6}, 400 \mathrm{MHz}\right) \delta 9.92(2 \mathrm{H}, \mathrm{t}, J=5.9 \mathrm{~Hz})$, $9.32(2 \mathrm{H}, \mathrm{t}, J=5.2 \mathrm{~Hz}), 8.52(2 \mathrm{H}, \mathrm{t}, J=5.7 \mathrm{~Hz}), 8.47(2 \mathrm{H}, \mathrm{d}$, $J=9.2 \mathrm{~Hz}), 8.27-8.02(23 \mathrm{H}, \mathrm{m}), 7.91(2 \mathrm{H}, \mathrm{s}), 5.21(4 \mathrm{H}, \mathrm{d}, J$ $=5.2 \mathrm{~Hz}), 4.67(4 \mathrm{H}, \mathrm{d}, J=5.6 \mathrm{~Hz}), 3.19-3.17(4 \mathrm{H}, \mathrm{m}), 1.44(4$ $\mathrm{H}, \mathrm{m}), 1.18-1.15(36 \mathrm{H}, \mathrm{m}), 0.80(6 \mathrm{H}, \mathrm{t}, J=6.8 \mathrm{~Hz}) ;{ }^{13} \mathrm{C} \mathrm{NMR}$ $\left(\mathrm{DMSO}-d_{6}, 100 \mathrm{MHz}\right) \delta 166.3,166.2,164.0,149.0,140.3,135.7$, 135.1, 133.2, 131.2, 130.7, 130.6, 129.1, 129.0, 128.6, 128.0, 127.8, 127.5, 127.2, 126.7, 125.7, 125.6, 125.2, 125.1, 124.5, 124.4, 123.7, 42.7, 41.6, 31.7, 29.5, 29.4, 29.2, 29.1, 26.9, 22.5, 14.4; HRMS calcd for $\mathrm{C}_{83} \mathrm{H}_{92} \mathrm{~N}_{7} \mathrm{O}_{6}$ 1282.7031, found $m / z$ 1282.7043 [M + H] $]^{+}$.

4-[(7-Diethylaminocoumarin-3-carbonyl)amino]butyl Phosphate (5). The coupling reaction of 7-diethylaminocoumarin-3carboxylic acid with 4-aminobutanol was performed in the presence of HBTU and diisopropylethylamine. Treatment with di-tert-butyl $\mathrm{N}, \mathrm{N}$-diisopropyl phosphoramidite in the presence of $1 \mathrm{H}$-tetrazole, followed by oxidation with $t$ - $\mathrm{BuOOH}$, gave the phosphorylation product ( $57 \%$ yield). After removal of the tert-butyl groups by TFA, the desired phosphate $\mathbf{5}$ was obtained in $96 \%$ yield.

Yellow solid, mp $190-192{ }^{\circ} \mathrm{C} ;{ }^{1} \mathrm{H}$ NMR (DMSO- $d_{6}, 400 \mathrm{MHz}$ ) $\delta 8.66-8.63(2 \mathrm{H}, \mathrm{m}), 7.66(1 \mathrm{H}, \mathrm{d}, J=8.9 \mathrm{~Hz}), 6.78(1 \mathrm{H}, \mathrm{d}, J$ $=8.9 \mathrm{~Hz}), 6.59(1 \mathrm{H}, \mathrm{s}), 3.83-3.80(2 \mathrm{H}, \mathrm{m}), 3.49-3.44(4 \mathrm{H}$, m), 3.31-3.30 (2 H, m), $1.56(4 \mathrm{H}$, br s $), 1.12(6 \mathrm{H}, \mathrm{t}, J=6.9$ $\mathrm{Hz}) ;{ }^{13} \mathrm{C}$ NMR (DMSO- $\left.d_{6}, 100 \mathrm{MHz}\right) \delta 162.1,161.8,157.2,152.4$, 147.6, 131.5, 110.1, 109.5, 107.7, 95.8, 64.8 (d, $J=5.1 \mathrm{~Hz}), 44.3$ $(2 \times), 38.4,27.5(\mathrm{~d}, J=6.8 \mathrm{~Hz}), 25.6,12.3(2 \times) ;{ }^{31} \mathrm{P}$ NMR (DMSO$\left.d_{6}, 162 \mathrm{MHz}\right) \delta 17.9$; HRMS calcd for $\mathrm{C}_{18} \mathrm{H}_{24} \mathrm{~N}_{2} \mathrm{O}_{7} \mathrm{P} 411.1399$, found $\mathrm{m} / \mathrm{z} 411.1387[\mathrm{M}-\mathrm{H}]^{-}$.

${ }^{1} \mathbf{H}$ NMR Titration for the Binding Studies. A solution of receptor was prepared, e.g., $2.4 \times 10^{-3} \mathrm{M}$ of receptor 4 in DMSO$d_{6}(99 \%)$, and an aliquot $(0.5 \mathrm{~mL})$ was transferred to a $5-\mathrm{mm}$ NMR tube. To the receptor solution was added a stock solution of substrate, e.g., GPP in DMSO- $d_{6}(0.3 \mathrm{M})$, by small portions in an incremental fashion. The chemical shifts of $N_{2}, N_{5}-\mathrm{H}$ in the receptor were monitored as a function of the substrate concentrations. Nonlinear regression analyses were used to determine the binding constants. $^{19}$

UV-Vis Spectral Measurement. The stock solutions of receptor 4 in anhydrous THF at various concentrations were prepared. Their corresponding UV-vis spectra were recorded at $298 \mathrm{~K}$ in a quartz cell $(1 \mathrm{~cm}$ width).

Fluorescent Titration for the Binding Studies. A solution of receptor was prepared, e.g., $5 \times 10^{-6} \mathrm{M}$ of receptor $\mathbf{4}$ in DMSO $(99 \%)$, and an aliquot $(2 \mathrm{~mL})$ was transferred to a $1-\mathrm{cm}$ fluorescence tube. To the receptor solution was added a stock solution of substrate, e.g., coumarin phosphate $\mathbf{5}$ in DMSO $\left(1 \times 10^{-3} \mathrm{M}\right)$, by small portions in an incremental fashion. The fluorescence spectra were recorded by excitation at the maximum absorption $(328 \mathrm{~nm})$. The relative fluorescence changes were recorded as a function of substrate concentrations. On the basis of 1:1 stoichiometry of the complex, the binding constant was calculated according to the following equation, and determined by the nonlinear least-squares curve-fitting method. ${ }^{21}$

$$
\left.y=f+[(d-\mathrm{f}) /(2 c)]\left\{K^{-1}+c+x-\left[\left(K^{-1}+c+x\right)^{2}-4 c x\right)\right]^{0.5}\right\}
$$

where $c$ is the receptor concentration; $d$ is the maximum change of fluorescence intensity at saturation; $f$ is the initial fluorescence intensity; $K$ is the association constant; $x$ is the substrate concentration; and $y$ is the fluorescence intensity.

Job's Plot for Determination of the Stoichiometry of Complexes. ${ }^{19}$ The stock solutions of receptor compound (e.g., receptor $4,1 \times 10^{-5} \mathrm{M}$ ) and the examined substrate [e.g., GPP, 1 $\left.\times 10^{-5} \mathrm{M}\right]$ in anhydrous DMSO were prepared in separate volumetric flasks. Nine sample solutions containing both receptor and substrate in different ratios (1/1 to 9/1) were prepared to maintain a total volume of $2.0 \mathrm{~mL}$. The mixture was shaken well, and the corresponding fluorescence emission curves were recorded. A plot according to $F-F_{0}(1-X)$ versus $X$ was made, where $F$ is the maximum change of fluorescence intensity at saturation, $F_{0}$ is the initial fluorescence intensity, and $X$ is the mole fraction of receptor.

Acknowledgment. We thank the National Science Council for financial support.

Supporting Information Available: Synthetic procedures, compound characterization, ${ }^{1} \mathrm{H}$ NMR titrations, fluorescence titrations, absorption spectra, and NMR spectra. This material is available free of charge via the Internet at http://pubs.acs.org.

JO802173B 